\title{
Sistem Informasi Penjualan di Toko Mebel Atmojo
}

\author{
Robby Rachmatullah*1, Ratna Herawati ${ }^{2}$, Koko Dwi Saputro ${ }^{3}$ \\ 1,2,3Program Studi Sistem Informasi, STMIK AUB, Surakarta, Indonesia \\ e-mail: *1 robby_r@stmik-aub.ac.id, ${ }^{2}$ ratna.herawati@stmik-aub.ac.id, ${ }^{3}$ kokods@gmail.com
}

\begin{abstract}
Abstrak
Mebel Atmojo adalah suatu badan usaha yang bergerak di bidang penjualan mebel seperti kursi tamu, lemari, meja makan dan lain-lain. adalah transaksi Penjualan Mebel. Proses jual beli tersebut terdiri dari penjualan ke customer. Sedangkan untuk proses penjualanya customer memilih barang yang akan dibeli, kemudian karyawan memberikan jumlah harga yang harus di bayarkan customer. Setelah customer membayarkan jumlah harga kemudian karyawan membuatkan nota. Untuk membantu proses transaksi penjualan di Toko Mebel Atmojo maka perlu dibuatkan Sistem Informasi Penjualan yang mampu melakukan transaksi pemesanan secara online, transaksi penjualan barang, pengolahan data barang dan stok barang serta mampu mengolah laporan dengan baik. Hasil perancangan sistem informasi penjualan ini menggunakan metode pengembangan sistem waterfall. Untuk analisa kelemahan sistem menggunakan analisa PIECES, sedangkan untuk menggambarkan alur data menggunakan Unified Modeling Languange yang terdiri dari usecase diagram, activity diagram, seuence diagram dan class diagram. Bahasa pemrograman yang digunakan adalah Android Studio sedangkan untuk pengolahan database menggunakan MySQL. Berdasarkan pengujian yang telah dilakukan menggunakan blackbox testing, sistem yang dibangun dapat membantu masalah yang dihadapi di Toko Mebel Atmojo.
\end{abstract}

Kata kunci: Mebel Atmojo, Sistem Informasi Penjualan, Android, $M y S Q L$

\section{PENDAHULUAN}

Sistem informasi sangat dibutuhkan dalam suatu organisasi baik instansi pemerintah, instansi swasta maupun lembaga-lembaga sosial sebagai yang dapat mempermudah dalam proses memberikan informasi terutama dalam proses pengolahan data dan pembuatan laporan. Pemanfaatan tekhnologi smartphone berbasis android juga dapat mempermudah dalam mencari informasi yang diinginkan dan sebagai alat komunikasi tanpa mengenal jarak dan waktu.

Sebelumnya sistem informasi penjualan terbatas dalam bentuk desktop, kini sistem informasi penjualan juga sudah mulai dikembangkan pada perangkat mobile berbasis android. Android merupakan sistem operasi berbasis linux yang memang diperuntukan bagi smartphone maupun komputer tablet. Hal ini cukup beralasan mengingat terdapat segudang kelebihan yang dimiliki aplikasi berbasis android. Dengan sistem informasi berbasis android, pengguna aplikasi dapat menggali informasi dimana saja dan kapan saja.

Mebel Atmojo adalah suatu badan usaha yang bergerak di bidang penjualan mebel seperti kursi tamu, lemari, meja makan dan lain-lain. Toko ini beralamatkan di Tegalombo kecamatan Kalijambe kabupaten Sragen. Adapun kegiatan utama yang di lakukan di Mebel Atmojo adalah transaksi Penjualan Mebel. Proses jual beli tersebut terdiri dari penjualan ke customer. Sedangkan untuk proses penjualanya customer memilih barang yang akan dibeli, kemudian karyawan memberikan jumlah harga yang harus di bayarkan customer. Setelah customer membayarkan jumlah harga kemudian karyawan membuatkan nota. 
Berdasarkan permasalahan yang ada maka peneliti tertarik untuk membangun aplikasi, yang dapat digunakan dan mempermudah proses transaksi penjualan serta pemesanan barang bagi customer dari luar. Semakin banyak market pasar yang dijangkau diharapkan mampu meningkatkan penjualan dari Mebel Atmojo. Selain digunakan untuk mengolah transaksi penjualan dan tansaksi pemesanan barang secara online aplikasi yang akan dibangun juga dapat melakukan pengolahan laporan pembelian dan laporan penjualan. Untuk selanjutnya dalam penyusunan Skripsi ini penulis menyajikan judul "Sistem Informasi Penjualan di Toko Mebel Atmojo".

\section{METODE PENELITIAN}

\subsection{Metode Pengumpulan Data}

a. Metode Wawancara

Metode wawancara adalah proses tanya jawab lisan dimana dua orang atau lebih berhadapan secara fisik yang satu dapat melihat muka yang lain dan mendengarkan dengan telinga akan suara sendiri (Nazir, 2005). Penulis melakukan wawancara dengan pemilik Mebel Atmojo.

b. Metode Observasi

Metode observasi adalah segala perhatian terhadap suatu obyek dengan menggunakan seluruh alat indera. Observasi dilakukan untuk memperoleh gambaran dan tingkahlaku yang utuh mengenai subyek yang akan diteliti (Nazir, 2005).

Observasi dilakukan menurut prosedur dan aturan tertentu sehingga dapat diulangi kembali oleh peneliti dan hasil observasi memberikan kemungkinan untuk ditafsirkan secara ilmiah. Dalam hal ini, pengamatan dilakukan langsung di Mebel Atmojo.

c. Metode Pustaka

Metode kepustakaan adalah teknik pengumpulan data dengan mengadakan studi penelaahan terhadap buku-buku, literatur-literatur, catatan-catatan, dan laporan-laporan yang ada hubungannya dengan masalah yang dipecahkan (Nazir, 2005).

Untuk memperkuat data-data dan masalah yang dihadapi, penulis mencari informasi lewat perpustakaan, internet, serta jurnal sebagai referensi untuk melakukan kegiatan penilitian tersebut.

\subsection{Pengembangan Sistem}

Dalam pembuatan Sistem Informasi Penjualan di Toko Mebel Atmojo, ini penulis menggunakan metode pengembangan sistem dengan metode Waterfall. Metode ini dipilih oleh penulis karena metode Waterfall mempunyai tahapan sistem yang terstruktur sehingga sesuai dalam ruang lingkup penelitian dan pengembangan sistem dengan metode Waterfall. Metode Waterfall adalah suatu proses pengembangan perangkat lunak berurutan, di mana kemajuan dipandang sebagai terus mengalir ke bawah (seperti air terjun) melewati fase-fase perencanaan, pemodelan, konstruksi, pengujian dan implementasi. Berikut adalah fase-fase pengembangan perangkat lunak berurutan / linear yang dapat dilihat pada gambar (Pressman, 2001).

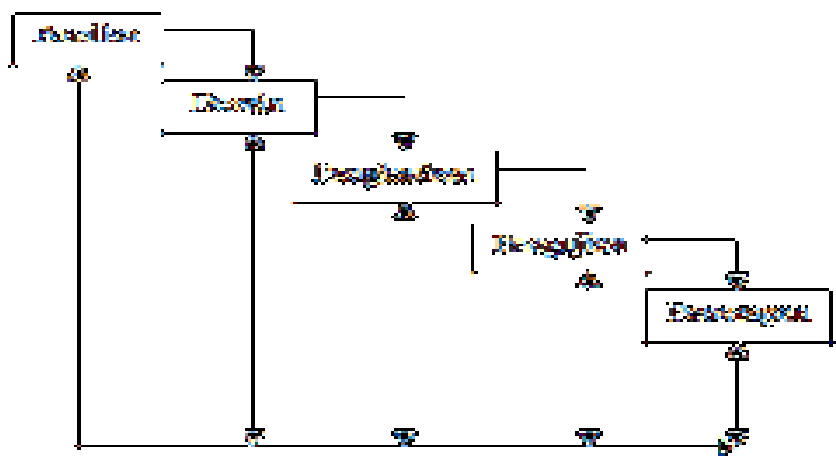

Gambar 1 Siklus Metode Waterfall

Tahapan Metode Waterfall:

a. Analisa 
Langkah ini merupakan analisa terhadap kebutuhan sistem. Pengumpulan data dalam tahap ini bisa melakukan sebuah penelitian, wawancara atau studi literatur. Seorang analisis akan menggali informasi sebanyak-banyaknya dari user sehingga akan tercipta sebuah sistem komputer yang bisa melakukan tugas-tugas yang diinginkan user. Tahapan ini akan menghasilkan dokumen user requirement atau bisa dikatakan sebagai data yang saling berhubungan dengan keinginan user dalam pembuatan sistem. Dokumen ini akan menjadi acuan sistem analisis untuk menterjemahkan kedalam Bahasa pemrograman.

b. Desain

Proses desain akan menterjemahkan syarat kebutuhan ke sebuah perancangan perangkat lunak yang dapat diperkirakan sebelum dibuat coding. Proses ini berfokus pada: struktur data, arsitektur perangkat lunak, representasi interface dan detail procedural. Tahapan ini akan menghasilkan dokumen yang disebut software requirement. Dokumen ini yang akan digunakan programmer untuk melakukan aktivitas pembuatan sistem.

c. Pengkodean

Coding merupakan penerjemah desiain dalam Bahasa yang bisa dikenali oleh komputer. Dilakukan oleh programmer yang akan menterjemahkan transaksi yang diminta oleh user. Tahapan ini merupakan tahapan secara nyata dalam mengerjakan suatu sistem. Dalam artian penggunaan komputer akan dimaksimalkan dalam tahapan ini.

d. Pengujian

Setelah pengkodean selesai maka akan dilakukan testing terhadap sistem yang telah dibuat. Tujuan testing adalah menemukan kesalahan-kesalahan terhadap sistem tersebut dan kemudian bisa diperbaiki.

e. Penerapan

Tahapan ini bisa dikatakan final dalam pembuatan sebuah sistem. Setelah melakukan analisa, desain dan pengkodean maka sistem yang sudah jadi akan digunakan oleh user.

\subsection{Usecase Diagram sistem informasi Penjualan di Toko Mebel Atmojo}

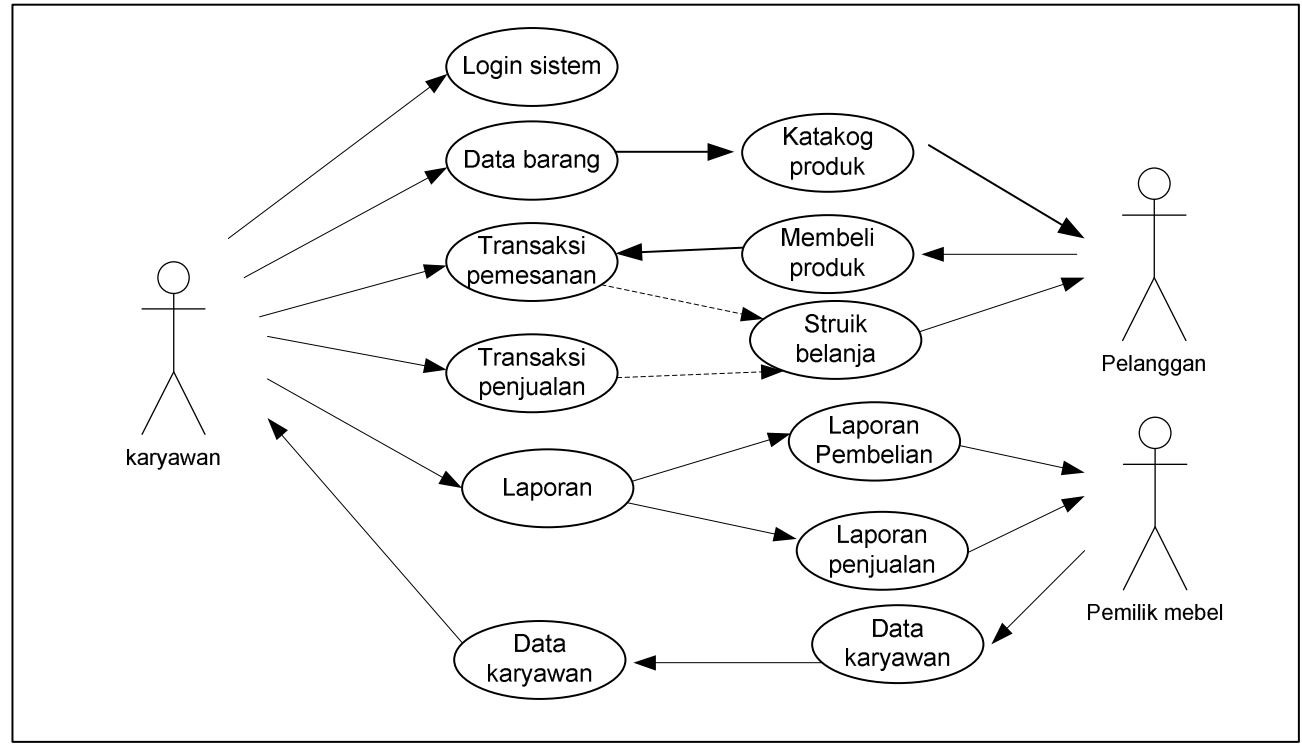

Gambar 2 Usecase Diagram sistem informasi Penjualan di Toko Mebel Atmojo

Karyawan login kedalam sistem kemudian memasukkan data barang dan akan diterima oleh pelanggan sebagai katalog produk. Katalog produk digunakan oleh pelanggan untuk memesan produk. Ketika memesan produk karyawan akan mengolah dan pelanggan akan menerima struk belanja. Kemudian karyawan juga dapat melakukan transaksi penjualan secara offline. Dari proses transaski tersebut, karyawan akan mengolah laporan yang nantinya diterima oleh owner yaitu laporan pembelian barantg dan laporan penjualan barang. 


\section{HASIL DAN PEMBAHASAN}

Dalam pembuatan aplikasi ini dibutuhkan suatu pembahasan untuk menguraikan program dan analisis dari hasil program yang telah dibuat. Tujuan pembahasan ini adalah untuk mengetahui apakah program yang dibuat sudah bekerja seperti yang diharapkan atau belum. Berikut adalah proses pembahasan interface atau antarmuka program

3.1. Halaman Pelanggan

1. Halaman Login Pelanggan

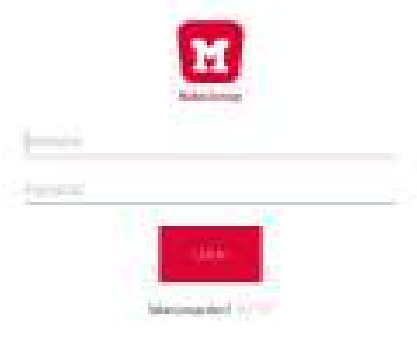

Gambar 3 Halaman Login Pelanggan

Pelanggan harus memasukkan username dan password untuk bisa masuk kedalam halaman utama admin. Setelah memasukkan username dan password kemudian pilih tombol "login". Jika tidak punya akun maka harus membuat terlebih dahulu.

2. Halaman Form Pemesanan Barang

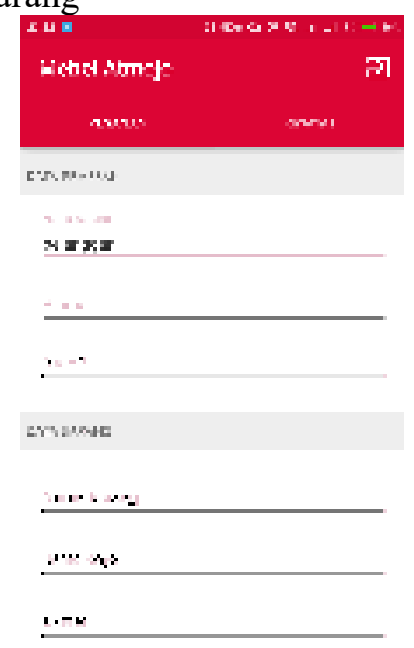

Gambar 4 Halaman Form Pemesanan Barang

3. Halaman List Pemesanan 


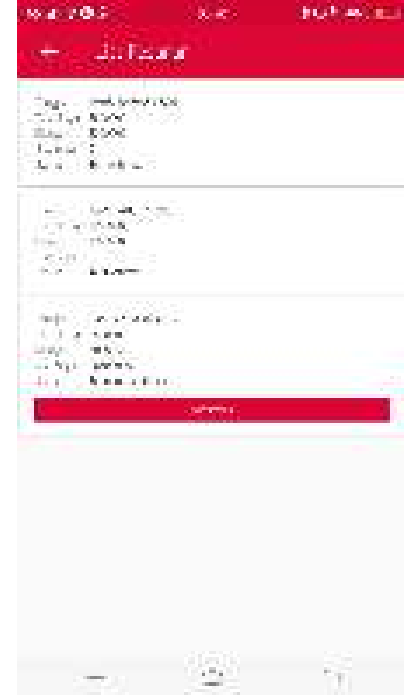

Gambar 5 Halaman List Pemesanan

Halaman list pesanan, menampilkan informasi data pesanan dari pelanggan. Informasi yang ditampilkan detail produk barang dan button konfirmasi untuk mengkonfirmasi pesanan dari pelanggan.

3.2. Halaman Karyawan

1. Halaman Login Admin

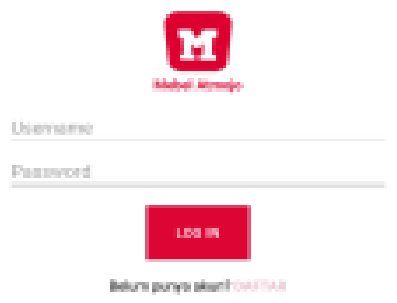

Gambar 6 Halaman login karyawan

Karyawamn harus memasukkan username dan password untuk bisa masuk kedalam halaman utama admin. Setelah memasukkan username dan password kemudian pilih tombol "login".

2. Halaman Menu Utama Karyawan 


\section{$\mathbf{4}$}

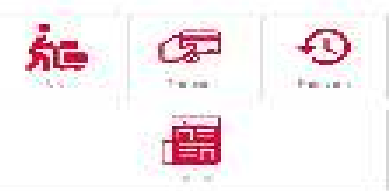

Gambar 5 Halaman menu utama karyawan

3. Halaman List Barang

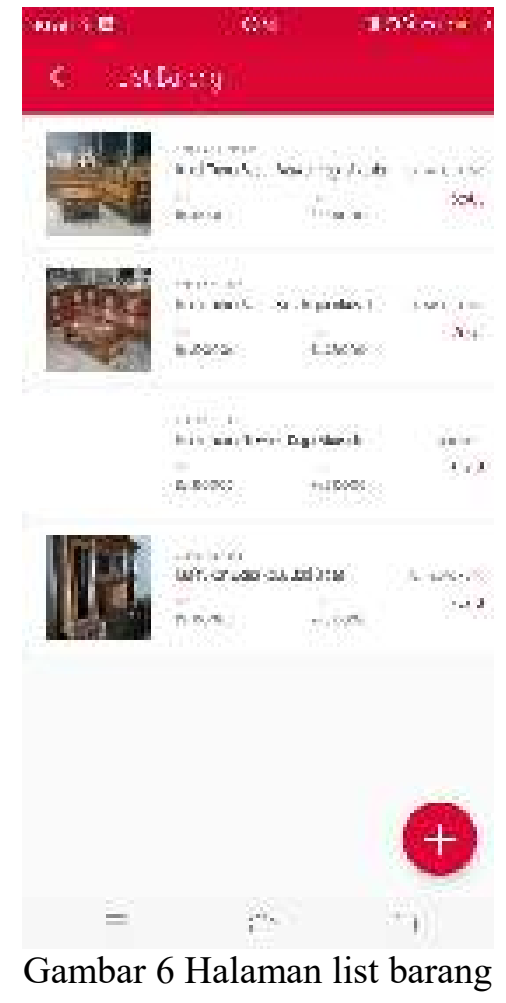

3.3. Halaman pemilik mebel

1. Login Admin 

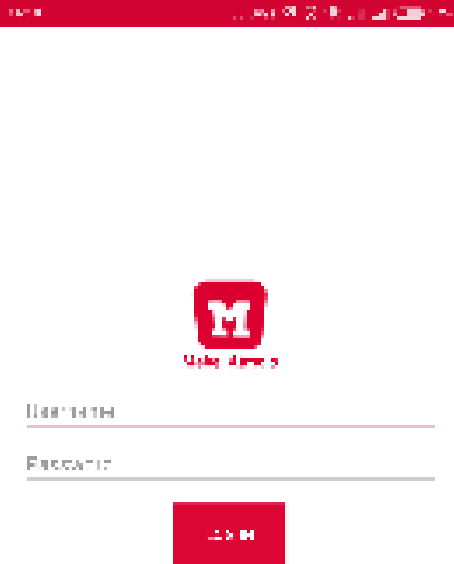

Gambar 7 Halaman login pemilik

Pemilik harus memasukkan username dan password untuk bisa masuk kedalam halaman utama admin. Setelah memasukkan username dan password kemudian pilih tombol "login".

2. Halaman Utama pemilik mebel

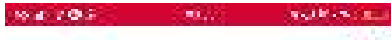

Gambar 8 Halaman utama pemilik mebel

Halaman utama pemilik, merupakan halaman utama pada user pengguna. Pemilik memiliki hak untuk menambah karyawan atau user dan melihat laporan penjualan atau laporan data barang

3. Halaman form list karyawan 


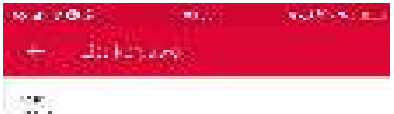

sic

Gambar 9 Halaman form list karyawan

Halaman form list karyawan, menampilkan daftar karyawan. Terdapat pilihan menu tambah karyawan pada bagian bawah kanan halaman.

4. Halaman form tambah data karyawan
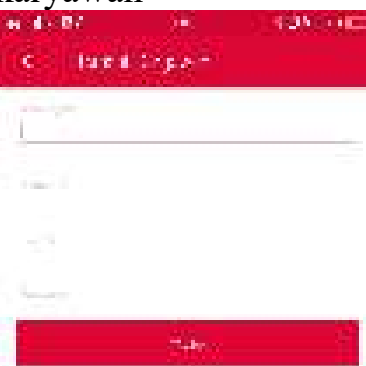

Gambar 10 Tambah data karyawan

Halaman form tambah data karyawan, menampilkan form yang digunakan untuk menambah data karyawan untuk selanjutnya disimpan kedalam database dan digunakan oleh karyawan login kedalam sistem.

5. Halaman menu laporan admin 


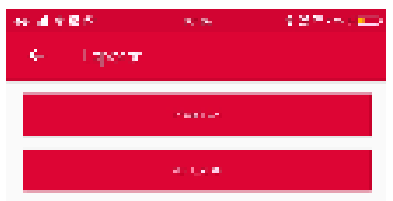

Gambar 11 Menu laporan

Menampilkan menu laporan yang diolah pada aplikasi Mebel Atmojo, yaitu laporan pembelian dan laporan penjualan.

6. Halaman laporan pembelian mebel
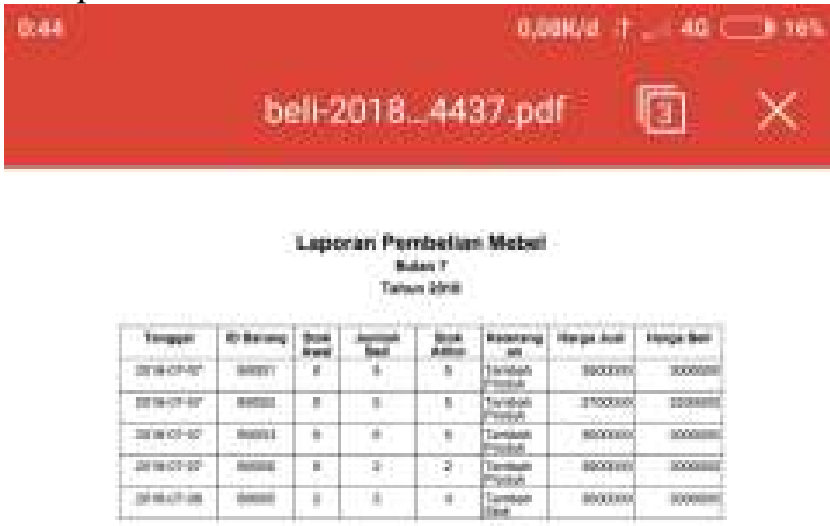

Gambar 12 Laporan pembelian mebel

Data pembelian barang atau barang masuk, ditampilkan menurut transaksi pembelian yaitu tanggal, id barang, stok awal, jumlah barang yang dibeli, stok akhir barang, keterangan barang, harga jual dan harga beli.

7. Halaman laporan penjualan mebel

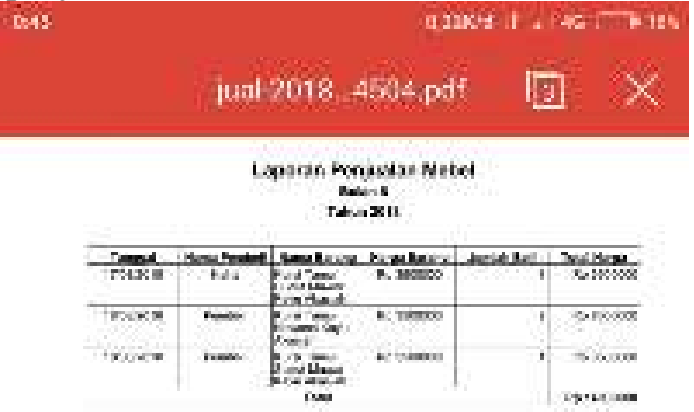

Gambar 13 Laporan penjualan mebel

Laporan penjualan mebel menampilkan keseluruhan transaksi penjualan, informasi pada laporan ini yaitu tanggal transaksi, nama pembeli, nama barang, harga barang, jumlah barang yang dibeli, total harga. Pada bagian bawah laporan terdapat jumlah total transaksi penjualan barang.

8. Halaman cetak struk belanja pelanggan 


\section{$\leftarrow$ nota-20180709_... Q A :}

\begin{tabular}{|c|c|c|c|}
\hline \multicolumn{4}{|c|}{ Penjualan Mebel } \\
\hline $\begin{array}{l}\text { Nama Pambali } \\
\text { Id Tranuakgi }\end{array}$ & \multicolumn{3}{|c|}{$\begin{array}{l}\text { Taucid } \\
\text { trans-20190709-001726 }\end{array}$} \\
\hline Tanggal & \multicolumn{3}{|c|}{ os:o7r:018-0ล:17:26 } \\
\hline Nama Earang & Harng & QTY & Tokal \\
\hline 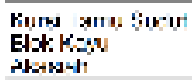 & $14 ; 2 \times 2000$ & $\cdot$ & $120 \% 10$ \\
\hline 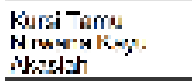 & Ros 850000 & $\cdot$ & Rosinx $\sin$ \\
\hline \multicolumn{3}{|c|}{ Toual } & คp 6200000 \\
\hline
\end{tabular}

Gambar 14 Cetak struk belanja pelanggan

Struk belanja digunakan untuk pembelian dari Mebel Atmojo untuk pelanggan, informasi yang ditampilkan pada struk belanja tersebut adalah nama pelanggan, id transaksi, nama barang, harga, quantity, total harga dan total bayar.

\section{KESIMPULAN}

Hasil perancangan Sistem Informasi Penjualan di Toko Mebel Atmojo menggunakan metode pengembangan sistem waterfall. Untuk perancangan proses terdiri dari flowchart, usecase diagram, activity diagram, sequence diagram, class diagram dan relasi antar tabel. Perancangan Sistem Informasi Penjualan di Toko Mebel Atmojo menggunakan Bahasa pemrograman Android Studio dan perancangan database menggunakan MySQL. Sistem Informasi Penjualan di Toko Mebel Atmojo, dibedakan menjadi tiga user yaitu pemilik mebel yang dapat mengelola data karyawan dan melihat laporan. Karyawan dapat mengelola data pembelian, data pemesanan, data penjualan dan laporan. Pelanggan dapat melakukan pemesanan barang dan melihat katalog produk. Sistem Informasi Penjualan di Toko Mebel Atmojo, dilengkapi dengan pengolahan laporan pembelian dan laporan penjualan barang yang dapat diakses oleh karyawan dan pemilik mebel. Sistem Informasi Penjualan di Toko Mebel Atmojo sudah di Implementasikan pada Toko Mebel Atmojo dan mampu meningkatkan pelayanan, kemudahan bertransaksi.

\section{SARAN}

Sistem Informasi Penjualan di Toko Mebel Atmojo, masih dapat dikembangkan lebih lanjut, yaitu gambar produk dibuat 3 dimensi, sehingga pelanggan dapat melihat gambar barang lebih detail lagi dan pembayaran melalui E-money.

\section{DAFTAR PUSTAKA}

[1] Decoster. 2012. Pengertian JavaDevelopment Kit: http://library.binus.ac.id diakses pada 2 Oktober 2017.

[2] Haryanto, dkk. 2018, Aplikasi Penjualan Mebel Titik Cerah Berbasis Android, Jurnal Go Infotech Jurnal Ilmiah STMIK AUB, Vol 24 No 2 2018, Hal 95-109

[3] Herawati, Prabowo Pudjo Widodo.2001. Menggunakan UML. Jakarta: Informatika.

[4] Jeffrey L. Whitten, Lonnie D. Bentley, Kevin C. 2001. System Analysis and Design Methods 5thEd. McGraw-Hill.

[5] Jogiyanto. 2005. Analisis \& Desain Sistem Informasi: Pendekatan Terstukter, Teori dan Praktis Aplikasi Bisnis. Yogyakarta: Penerbit Andi. 
[6] Kristanto. 2003. Konsep dan Perancangan Basis Data. Yogyakarta: Penerbit Andi.

[7] Ladjamudin, Albahra. 2005. Analisis dan Desain Sistem Informasi. Yogyakarta: Graha Ilmu.

[8] Mulyanto, Agus. 2009. Sistem Informasi Konsep dan Aplikasi. Yogyakarta: Pustaka Pelajar.

[9] Nazir, Muhamad. 2005. MetodePenelitian. Jakarta: Ghalia Indonesia

[10] Pressman, Roger S. 2001. Software Engineering: A Practitioner's Approach Fifth Edition. Singapore: The Mc-Graw-Hill Companies.

[11] Safaat, Nazrudin.2012. Android Pemrograman Aplikasi Mobile Smartphone dan Tablet PC Berbasis Android. Bandung: Informatika Bandung.

[12] Sutabri, Tata. 2005. Sistem Informasi Manajemen. Yogyakarta: Andi Offset.

[13] Usman, Husnaini dan Akbar, Purnomo Setyadi. 2000. Metodologi Penelitian Sosial. Jakarta: PT. Bumi Aksara. 